Research Article

\title{
Response of Zinnia Cultivars to Different Levels of Humic Acid
}

\author{
Imran Ullah Khan*, Noor U1 Amin, Sayyed Hamad Ahmad Shah, Maqsood Khan, Shehzad Ahmad and \\ Syed Aizaz Ali Shah
}

Department of Horticulture, The University of Agriculture Peshawar, Khyber Pakbtunkbwa, Pakistan.

\begin{abstract}
This experiment was performed in Ornamental Nursery at the Department of Horticulture, The University of Agriculture Peshawar during 2016. The experiment was laid out on Randomized Complete Block Design (RCBD) with split plot arrangement and replicated three times. Seedlings of Zinnia cultivars (Dahlia, Candy Cane, and Dream land) were tested against five different levels of humic acid (0, 2.5, 5, 7.5, and $\left.10 \mathrm{~kg} \mathrm{ha}^{-1}\right)$. Experimental data was collected on days to flowering, plant height $(\mathrm{cm})$, number of leaves plant ${ }^{-1}$, leaf area $\left(\mathrm{cm}^{2}\right)$, number of branches plant ${ }^{-1}$, number of flower plant ${ }^{-1}$, diameter of flower $(\mathrm{cm})$, fresh flower weigh $(\mathrm{g})$, flower stalk length $(\mathrm{cm})$ and flower vase life. The above mentioned parameters are highly influenced by most of humic acid levels. The increment value were shown on humic acid at the rate of $10 \mathrm{~kg}$ $\mathrm{ha}^{-1}$ for days to flowering $\left(21.2\right.$ days), plant height $(85.0 \mathrm{~cm})$, number of leaves plant ${ }^{-1}(183.7)$, leaf area $(56.7$ $\left.\mathrm{cm}^{2}\right)$, number of branches plant ${ }^{-1}(15.9)$, number of flower plant ${ }^{-1}(18.4)$, flower diameter $(9.8 \mathrm{~cm})$, fresh flower weight $(12.9 \mathrm{~g})$, flower stalk length $(16.9 \mathrm{~cm})$ and flower vase life $(7.0$ days $)$, while among different cultivars, "Dahlia" showed minimum days to flowering (23.9), maximum plant height $(96.3 \mathrm{~cm})$, flower weight $(14.7 \mathrm{~g})$, flower diameter $(9.6 \mathrm{~cm})$ and leaf area $\left(62.1 \mathrm{~cm}^{2}\right)$. Cultivar Candy Cane showed maximum number of leaves plant $^{-1}(190)$, number of branches plant ${ }^{-1}(14.6)$, flower stalk length $(17.1 \mathrm{~cm})$, and flower vase life $(6.1$ days), whereas number of flower plant ${ }^{-1}(16)$ was found maximum in cultivar "Dream land". The cultivar and humic acid interaction was not significant in all parameters. Zinnia $\mathrm{Cv}$. Dahlia and Candy Cane both adapted to the agro-climatic conditions of Peshawar. Humic acid level at the rate of $10 \mathrm{~kg} \mathrm{ha}^{-1}$ showed better results upon application to Zinnia and hence it is suggested for best production.
\end{abstract}

Received | December 20, 2017; Accepted | October 08, 2020; Published | June 09, 2021

*Correspondence | Imran Ullah Khan, The University of Agriculture Peshawar, Khyber Pakhtunkhwa, Pakistan; Email: i_khan94@yahoo.com Citation | Khan, I.U., N.U. Amin, S.H.A. Shah, M. Khan, S. Ahmad and S.A.A. Shah. 2020. Response of zinnia cultivars to different levels of humic acid. Sarhad Journal of Agriculture, 37(2): 706-713.

DOI | https://dx.doi.org/10.17582/journal.sja/2021/37.2.706.713

Keywords | Humic acid, Zinnia, Leaf area, Flower size, Flower vase life

\section{Introduction}

Z innia (Zinnia elegans) belongs to the family Asteraceae. It is a summer annual cut flower and getting popular due to its several colorful blooms. It is originated from Central America and Mexico. "Blue Point" and "Oklahoma" are the most grown zinnia cultivars are considered the colorfully blooms and better performance (Dole, 1999). Zinnia is annual and perennial plants and its flowers display uniform colors, bright, strong stems with long vase life and disease resistant plants. Zinnia is the most familiar species and a plant of hot and warm climate. Conventionally, taller cultivars of Zinnia are used in beds and borders, for cut flowers but the dwarf cultivars in window planters, and containers (Jana and Pal, 1991). Zinnia is propagated through seeds and seeds are directly sown in pots, and then transplanted in to field. Zinnia required $23-27^{\circ} \mathrm{C}$ for germination in five to seven days. When seedlings at 
about 3-6 weeks old are transplants in field or beds (Schoellhorn et al., 2004). Humic acid is a systematic binding bio-stimulant that affects plant growth and development and enhance yield (Nardi et al., 2004). Humic acid improve the organic, chemicals and physicals property of soil (Varanimi et al., 1995; Keeling et al., 2003; Mikkelson, 2005). Humic acid plays an important role in controlling soil borne diseases as well as improving of soil health, mineral, nutrients uptake by plants (Mouromical et al., 2011). Humic acid help in plant nutrition, soil fertilities and the attractive connections with plants nutrient such as calcium $(\mathrm{Ca})$, manganese $(\mathrm{Mn})$, magnesium $(\mathrm{Mg})$, copper $(\mathrm{Cu})$, zinc $(\mathrm{Zn})$ and iron $(\mathrm{Fe})$ and also decreases their poisonousness, increases uptake rate by plant roots and prevents leaching (Pettit, 2004). The main objective of the present study was to study the response of different zinnia cultivars to various levels of humic acid in terms of growth and other characteristics.

\section{Materials and Methods}

This experiment was performed at Ornamental Nursery at the Department of Horticulture, The University of Agriculture Peshawar, Khyber Pakhtunkhwa, Pakistan during 2016. Modulated trays were used for nursery rising. Which was kept in green house until germination of seeds occurred. The soil media was incorporated with peat moss, coconut husk and leaf mold to improve germination. After sowing the seeds were constantly watered by sprinkler irrigation. When the seedlings reached six to seven leaves stage, it was transplanted to the experimental field. Thus, the experiment was laid out on Randomized Complete Block Design (RCBD) with split plot arrangement and replicated three times. The experimental unit was $3.51 \mathrm{~m}^{2}$ having three rows of zinnia with 30 and $50 \mathrm{~cm}$ plant to plant and row to row distance respectively. Humic acid at various levels was assigned to main plot, while cultivars (Dahlia, Candy Cane and Dream Land) were maintained in sub plots. Humic acid levels were applied to the soil after transplantation of zinnia. According to the weight, $\mathrm{H}_{\mathrm{o}} 0 . \mathrm{H}_{1} 2.5, \mathrm{H}_{2} 5, \mathrm{H}_{3} 7.5$ and $\mathrm{H}_{4} 10 \mathrm{~kg} \mathrm{ha}{ }^{-1}$ humic acid was converted into powder form, dissolved in water separately and were kept into gallons and applied by soil irrigation to the plants. All other agronomic practices were kept uniform for all treatments which included weeding, hoeing, fertilization and irrigation.

\section{Studied variables}

Various morphological traits were studied during the experiment. Days to flowering was counted from the date of transplantation to first flower the number of days were recorded for each treatment and then mean was calculated. Similarly, for plant height, shoot was measured randomly in each treatment with measuring tape and then mean was obtained. In case of number of leaves, all leaves were counted on plants randomly selected in each replication. Leaf area was recorded by using leaf area meter. Number of branches were counted in randomly selected five plants from each replication and then average was determined. For number of flowers total flowers were counted on randomly selected plants in each replication. Flower diameter was measured in randomly selected flowers from each with vernier caliper on two opposite sides of flower. For weight of flowers, digital balance was used and their average was calculated. Flowers were randomly selected. To measure the length of flower stalk, measuring tape was used and then mean was calculated. For Flower vase life determination, randomly selected flowers cut with long stalk and then placed in bottles contain normal tape water. Data was collected until wilting of petals occurred.

\section{Statistical analysis}

For statistical analysis Statistix 8.1 software was used, while for mean comparison LSD test was used with $5 \%$ alpha value (Steel et al., 1997).

\section{Results and Discussion}

\section{Days to flowering}

Mean values in Table 1 for humic acid levels and cultivars revealed highly significant differences, however the interaction was non-significant. The mean data of early flowering (21 days) was observed for the emergence of flowers by the use of $10 \mathrm{~kg} \mathrm{ha}^{-1}$ humic acid. While later flowering was occurred in control plots (32 days). Earliest flowering days among the cultivar was observed in dream land cultivar which was (23 days) and later flowering (28 days) was observed in cultivar candy cane. Data revealed that days to flowering decreased significantly with increase in concentration of humic acid. It might be due to the fact that light synthesis, chlorophyll content and rapid growth of plant as a result of high nutrients uptake favored by humic acid application. Lilium plant leads to earlier flowering treated with humic acid as compared with untreated plants as reported by Memon and Khetran (2014). 
Table 1: Days to flowering, plant height (cm), number of leaves plant ${ }^{-L}$, leaf area $\left(\mathrm{cm}^{2}\right)$ and number of branches plant $^{-L}$ as affected by various levels of humic acid and zinnia cultivars.

\begin{tabular}{|c|c|c|c|c|c|}
\hline Humic acid levels (kg) & $\begin{array}{l}\text { Days to } \\
\text { flowering }\end{array}$ & $\begin{array}{l}\text { Plant height } \\
\text { (cm) }\end{array}$ & $\begin{array}{l}\text { Number of leaves } \\
\text { plant }^{-1}\end{array}$ & $\begin{array}{l}\text { Leaf area } \\
\left(\mathrm{cm}^{2}\right)\end{array}$ & $\begin{array}{l}\text { Number of branches } \\
\text { plant }^{-1}\end{array}$ \\
\hline 0 & $32.1 \mathrm{a}$ & $71.4 \mathrm{c}$ & $150.0 \mathrm{~d}$ & $46.7 \mathrm{~d}$ & $10.3 \mathrm{c}$ \\
\hline 2.5 & $29.1 \mathrm{~b}$ & $75.9 \mathrm{bc}$ & $160.5 \mathrm{c}$ & $51.2 \mathrm{c}$ & $11.7 \mathrm{bc}$ \\
\hline 5 & $26.1 \mathrm{c}$ & $77.9 \mathrm{~b}$ & $167.9 \mathrm{bc}$ & $53.3 \mathrm{~b}$ & $12.1 \mathrm{bc}$ \\
\hline 7.5 & $24.3 \mathrm{~d}$ & $79.1 \mathrm{~b}$ & $174.9 \mathrm{~b}$ & $54.2 \mathrm{~b}$ & $13.4 \mathrm{~b}$ \\
\hline 10 & $21.2 \mathrm{e}$ & $85.0 \mathrm{a}$ & $183.7 \mathrm{a}$ & $56.7 \mathrm{a}$ & $15.9 \mathrm{a}$ \\
\hline LSD at $\alpha 5 \%$ & 1.6 & 5.8 & 7.16 & 1.89 & 2.19 \\
\hline \multicolumn{6}{|l|}{ Zinnia cultivars } \\
\hline Dhalia & $26.8 \mathrm{~b}$ & $96.7 \mathrm{a}$ & $162.6 \mathrm{~b}$ & $62.1 \mathrm{a}$ & $12.6 \mathrm{~b}$ \\
\hline Candy cane & $28.9 \mathrm{a}$ & $91.8 \mathrm{~b}$ & $190.2 \mathrm{a}$ & $46.7 \mathrm{c}$ & $14.6 \mathrm{a}$ \\
\hline Dream land & $23.9 c$ & $45.1 \mathrm{c}$ & $149.4 \mathrm{c}$ & $48.4 \mathrm{~b}$ & $10.9 \mathrm{c}$ \\
\hline LSD at $\alpha 5 \%$ & 1.55 & 3.69 & 7.04 & 1.63 & 121 \\
\hline $\begin{array}{l}\text { Humic acid } \times \text { Zinnia cultivars } \\
\text { interaction }\end{array}$ & NS & NS & NS & NS & NS \\
\hline
\end{tabular}

Table 2: Number of flowers plant ${ }^{-1}$, flower diameter (cm), flower fresh weight (g), flower stalk length (cm) and flower vase life as affected by various levels of humic acid and zinnia cultivars.

\begin{tabular}{llllll}
$\begin{array}{l}\text { Humic acid } \\
\text { levels } \mathbf{( k g})\end{array}$ & $\begin{array}{l}\text { Number of flowers } \\
\text { plant }^{-1}\end{array}$ & $\begin{array}{l}\text { Flower diameter } \\
(\mathbf{c m})\end{array}$ & $\begin{array}{l}\text { Flower fresh } \\
\text { weight }(\mathbf{g})\end{array}$ & $\begin{array}{l}\text { Flower stalk } \\
\text { length }(\mathbf{c m})\end{array}$ & $\begin{array}{l}\text { Fower vase } \\
\text { life }\end{array}$ \\
\hline 0 & $10.9 \mathrm{~d}$ & $7.7 \mathrm{c}$ & $9.2 \mathrm{~d}$ & $9.2 \mathrm{~d}$ & $13.2 \mathrm{~d}$ \\
2.5 & $12.6 \mathrm{~cd}$ & $8.0 \mathrm{bc}$ & $10.1 \mathrm{~cd}$ & $10.1 \mathrm{~cd}$ & $14.0 \mathrm{c}$ \\
\hline 5 & $14.3 \mathrm{bc}$ & $8.3 \mathrm{bc}$ & $11.1 \mathrm{bc}$ & $11.1 \mathrm{bc}$ & $14.3 \mathrm{c}$ \\
7.5 & $15.4 \mathrm{~b}$ & $8.6 \mathrm{~b}$ & $11.4 \mathrm{~b}$ & $11.4 \mathrm{~b}$ & $15.6 \mathrm{~b}$ \\
10 & $18.4 \mathrm{a}$ & $9.8 \mathrm{a}$ & $12.9 \mathrm{a}$ & $12.9 \mathrm{a}$ & $16.9 \mathrm{a}$ \\
LSD at $\alpha 5 \%$ & 2.71 & 0.77 & 1.14 & 1.14 & 0.72 \\
Zinnia cultivars & & & & & \\
Dhalia & $14.2 \mathrm{~b}$ & $9.6 \mathrm{a}$ & $162.6 \mathrm{~b}$ & $14.7 \mathrm{a}$ & $15.8 \mathrm{~b}$ \\
Candy cane & $12.8 \mathrm{c}$ & $7.0 \mathrm{c}$ & $190.2 \mathrm{a}$ & $9.0 \mathrm{~b}$ & $17 . \mathrm{a}$ \\
Dream land & $16.0 \mathrm{a}$ & $8.8 \mathrm{~b}$ & $149.4 \mathrm{c}$ & $9.1 \mathrm{~b}$ & $11.5 \mathrm{c}$ \\
LSD at $\alpha$ 5\% & 1.35 & 0.73 & 7.04 & 1.75 & 0.83 \\
$\begin{array}{l}\text { Humic acid } \times \text { Zinnia cultivars } \\
\text { interaction }\end{array}$ & $\mathrm{NS}$ & $\mathrm{NS}$ & $\mathrm{NS}$ & $\mathrm{NS}$ & $\mathrm{NS}$
\end{tabular}

\section{Plant height $(\mathrm{cm})$}

The results in Table 1 regarding plant height $(\mathrm{cm})$ showed that humic acid levels influenced zinnia cultivars significantly while their interaction was observed non-significant. The table of mean values showed that largest plants $(85 \mathrm{~cm})$ were recorded when the application of humic acid was applied at 10 $\mathrm{kg} \mathrm{h}^{-1}$, followed by $7.5 \mathrm{~kg} \mathrm{ha}{ }^{-1}$ humic acid $(79.1 \mathrm{~cm})$, although shorter plants were observed in untreated plots $(71.4 \mathrm{~cm})$. Similarly, significant variation in plant height was noticed regarding zinnia cultivars, cultivar dahlia showed maximum plant height (96.7 $\mathrm{cm}$ ) and lowest plant height was noticed in cultivar dream land $(45.1 \mathrm{~cm})$. Plant heights are clearly affected by the application of humic acid. It may be due to extra uptake of nitrogen, sulfur and phosphorus. Which increased plant growth. The availability of both micro and macro nutrients are enhanced due humic acid application. The mitotic activity of apical meristem is positively influenced by higher uptake of calcium and consequently produced higher plants height (Ahmadian et al., 2011). Mostly plant height of zinnia increased due to humic acid which leads to increased humidity, storage media and better absorption of nutrients from the soil (Memon et al., 2014). The present consequences are in accordance 
with Mohammadipour et al., (2012) who observed maximum plant height of marigold when $2000 \mathrm{mg}$ $\mathrm{L}^{-1}$ humic acid was applied as compared to control.

\section{Number of leaves plant ${ }^{-1}$}

Results in Table 1 regarding number of leaves plant ${ }^{-1}$ showed that humic acid levels influenced growth of zinnia cultivars significantly. However, non-significant interaction effects were observed for humic acid and cultivars. Analysis of data indicated that maximum (183.7) number of leaves plant ${ }^{-\mathrm{I}}$ was noticed in plots where humic acid at rate of $10 \mathrm{~kg} \mathrm{ha}^{-1}$ was applied followed by $7.5 \mathrm{~kg}$ ha and lower (150.0) leaves plant ${ }^{-1}$ was resulted in control plot. As concerned cultivar, more leaves plant ${ }^{-1}$ was noted in cultivar candy cane (190.2), followed by cultivar dahlia (162.6) and less number of leaves plant ${ }^{-1}$ were obtained in cultivar dream land (149). By the soil application of humic acid resulted significant increase in number of leaves plant $^{-1}$. It might be due to the positive effects of humic acid on nutrients uptake, which increase rate of photosynthesis and ultimately number of leaves increased. Humic acid acts like plant growth regulator to maximize chlorophyll content and as a result improve the vegetative growth. High concentrations of humic acid $\left(2000 \mathrm{mg} \mathrm{L}^{-1}\right)$ have a positive effect on number of leaves per plant especially in marigold in comparison to untreated plants (Kamari et al., 2010). Our results are also resembled with (Khodakhah et al., 2014) who stated that humic acid have positive effect on number of leaves plant ${ }^{-1}$ of tuberose with increase doses from 0 to $1000 \mathrm{ppm}$. Gladiolus plants which receive $7000 \mathrm{ml}$ humic acid increase number of leaves plant ${ }^{-1}$ as compared to control (Ahmad et al., 2013).

\section{Leaf area $\left(\mathrm{cm}^{2}\right)$}

Data regarding leaf area is presented in Table 1. Which show significant effect of humic acid on Dhalia cultivar. However, non-significant interactive effects were observed for humic acid and cultivars. Mean table for leaf area expressed that highest leaf area $\left(56.7 \mathrm{~cm}^{2}\right)$ treated with $10 \mathrm{~kg} \mathrm{ha}{ }^{-1}$ humic acid, at par with $7.5 \mathrm{~kg} \mathrm{ha} \mathrm{g}^{-1}$ and humic acid $\left(54.2 \mathrm{~cm}^{2}\right)$. However, minimum leaf area $\left(46.7 \mathrm{~cm}^{2}\right)$ was noted in untreated plants. Data regarding to cultivars, the highest leaf area was observed in cultivar dahlia $\left(62.1 \mathrm{~cm}^{2}\right)$, followed by cultivar dream land (48.4) and minimum leaf area was observed in cultivar Candy cane $\left(46.7 \mathrm{~cm}^{2}\right)$. The present observations showed that leaf area was increasing with a slight change in the concentration of humic acid. It may be attributed to humic acid availability for longer periods imposing direct effect on photosynthetic activities. Gladiolus plants produce greater leaf area with the application of $7000 \mathrm{ml} \mathrm{ha}^{-1}$ while in control they were found lowest leaf area (Ahmad et al., 2013). Humic acid concentrations significantly increased leaf area (Fan et al., 2014). Further they stated that humic acid increased the rate of photosynthesis, as a result high biomass accumulation occur which enhanced the growth of leaf (Baldotto and Lilian, 2013). Humic acid increased the leaf area as compared to the control treatment (El-Khateeb et al., 2011). The maximum leaf area was due to photosynthetic pigments contents with increased humic acid concentration and the production of carotenoids initiated which guard chlorophyll from oxidative damage ensuing in increase in sufficient cell in leaves, chloroplast per cell and gradually leaf area, the current results are in agreement with (Yildirim, 2007), who's reported that leaf area increased with increasing in humic acid concentration.

\section{Number of branches plant ${ }^{-1}$}

Mean data for Number of Branches Plant ${ }^{-1}$ of various Zinnia cultivars under humic acid application was found significant, which is shown in Table 1 . However, the interaction was not significant. Maximum branches plant $^{-1}(15.9)$ were observed when $10 \mathrm{~kg} \mathrm{ha}^{-1}$ humic acid was applied, followed by $7.5 \mathrm{~kg} \mathrm{ha}^{-1}$ humic acid (13.4), however lower number of branches were observed in control treatment with a mean value of (10.3) which is statically similar with $2.5 \mathrm{~kg} \mathrm{ha}^{-1}$ level. Among cultivars candy cane has maximum branches plant ${ }^{-1}$ with a mean value of (14.6) followed by cultivar dahlia (12.6) and minimum number of branches plant $^{-1}$ were observed in cultivar dream land (10.9). A positive correlation was observed among humic acid application and number of branches. This may be due to maximum absorption of nutrients from the soil as result of humic acid activity, which eventually increased the number of shoot tremendously. Similar findings were also observed by Bryan (1976), who reported that Humic acid effect on number of branches indicted that treatment of $2000 \mathrm{mg} / 1$ resulted 14.30 branches in comparison to control (5.84 branches). Memon et al. (2014) also found similar result, which were achieved by the application of $4 \mathrm{~g} / 2 \mathrm{~m}^{2}$ humic acid. They also found positive association of number of braches per plant with yield. These finding justify the findings of (Mohammadipour et al., 2012), who 
conform our results that humic acid $2000 \mathrm{mg} \mathrm{L}^{-1}$ significantly increased the number of branches in plant.

\section{Number of flowers plant ${ }^{-1}$}

Number of flowers per plant of Zinnia cultivars was significantly affected by humic acid application. However, interactive effects are non-significant. The mean values revealed that application of humic acid at the rate of $10 \mathrm{~kg} \mathrm{ha}^{-1}$ produced maximum (18.4) number of flower plant ${ }^{-1}$ which is statistically at par with $7.5 \mathrm{~kg} \mathrm{ha}^{-1}$ humic acid (15.4) while least number of flowers plant ${ }^{-1}$ were noted in untreated plots (10.9). Number of flowers plant ${ }^{-1}$ was significantly varied among cultivar and cultivar dream land has more (16) number of flowers per plants which is followed by cultivar dahlia (14.2), the minimum flowers cultivar candy cane plants with a mean value of (12.8). Flower production of zinnia is directly proportional to number of flowers plant ${ }^{-1}$. Flowers increased with increasing levels of humic acid. It is due to positive effect on absorption of nutrients from the soil which finally increased number of flowers per plant. Similarly, Memon et al. (2014) explored that zinnia gave 15.77 $\%$ maximum flowers when used high dose of humic acid $\left(4 \mathrm{~g} / 2 \mathrm{~m}^{2}\right)$ over that zinnia plant which were not treated. Humic acid also enhanced efficiency of the soil, minimizes the utilization of other fertilizers sources to be added to the soil (Mohamadineia et al., 2012). It influences the dry biomass of plant and assists absorption of plant nutrients (Shahmaleki et al.,2010).Humic acid applied @ $2000 \mathrm{mg} \mathrm{L}^{-1}$ resulted six times more flowers per plant in comparison to control. Results obtained are further justified by Tina et al. (2015) that observed the influence of foliar spray of humic acid on growth and production of marigold and further mentioned that the more and less quantity of fresh flower yield were achieved when $500 \mathrm{mg} \mathrm{L}^{-1}$ humic acid was applied. An increase has also been observed in gerbera flowers with a proportionate increased in number by the application of $500 \mathrm{mg} \mathrm{L}^{-1}$ of humic acid (Nikbakht et al., 2008). Furthermore, Baldotto and Baldotto (2013) reported that numbers of flowers were significantly increased in ornamental sunflower with the soil application of humic acid.

\section{Flower stalk length (cm)}

Data regarding flower stalks length is shown in Table 2 which indicated that humic acid levels significantly affect flower stalks length of Zinnia cultivars, however interactive effect was non-significant. When humic acid was applied at the rate of $10 \mathrm{~kg} \mathrm{ha}^{-1}$ boosted the flower stalk length up to $16.9 \mathrm{~cm}$ followed by $7.5 \mathrm{~kg}$ $\mathrm{ha}^{-1}$ levels of humic acid, whereas minimum flower stalk length $(13.2 \mathrm{~cm})$ was observed in control plot. Among the cultivars, maximum flower stalk length was recorded in cultivar candy cane $(17.1 \mathrm{~cm})$, followed by cultivar dahlia $(15.8 \mathrm{~cm})$. While minimum flower stalk was observed in cultivar dream land $(11.5 \mathrm{~cm})$.

Humic acid improve nutrient uptake and improve root growth by making the soil favorable for root penetration. It leads to increase photosynthetic rate resulting high amount of energy production. This energy is used for growth purposes, so due to high amount of food present for synthesis of valuable compounds results in increased growth. It ultimately increased stalk growth like other growth parameters. Humic acid can increase the uptake of nutrients which enhanced the photosynthesis and leaf growth, this lead to enhance the growth rate which improves stalk length (Atiyeh et al., 2002). Humic acid has an essential role in flower stalk length even if provided in small amount in ornamental plants (Ahmad et al., 2013). Furthermore, they stated that flower stalk length improves with the application of humic acid because it plays important role in cell elongation as well as cell expansion. The current research findings are also supported by Khodakhah et al. (2014) who recorded increased flower stalk length while increasing humic acid concentrations to $1000 \mathrm{ppm}$ as compared to control.

\section{Flower vase life}

Regarding flower vase life mean data is shown in Table 2 which indicated that humic acid levels and different cultivars significantly affect flower vase life, however interaction effects were non-significant. The results manifested that highest flower vase life ( 7 days) was obtained when humic acid was applied $10 \mathrm{~kg}$ ha ${ }^{1}$, similarly (6.1 days) were observed in treatment 7.5 $\mathrm{kg} \mathrm{ha}{ }^{-1}$ humic acid whereas least number of flower vase life (4.7 days) was noted in control plots. Among the zinnia cultivars, maximum vase life was resulted in cultivar candy cane (6.1 days) that is statically at par with cultivar dahlia (5.6 days), whereas minimum flower vase life was recorded in cultivar dream land (5.1 days). Reduction in ethylene synthesis occurs due the application of humic acid which may be the cause of longer vas life. Increased in humic acid concentration prolong vase life of zinnia cut flower. These results resemble with those reported by Yazdani et al. (2014), 
who noted that flower shelf life was improved with humic acid and tested Gerbera flowers against the humic acid and reported that it reduces the ethylene production which contribute in increasing the shelf life of flower after harvesting, whereas the quality of ethylene has basic role in extending shelf life of flower. Vase life increased up to 15 days with effect of $50 \mathrm{ml} / 1$ humic acid level in various Gerbera cultivars in cut flowers specially (Khenizy et al., 2013; Ali et al., 2008). Kumar et al. (2003) achieve same objective and stated that humic acid can do activity similar to auxin and improve the soil physical properties such as water holding capacity and nutrient use efficiency which may be important factor for well floral growth and also extending the shelf life of harvested flower (Kulikova et al., 2010; Evans and Li, 2010; Rajiv and Misra, 2000). Ali et al. (2014) also reported that humic acid treatment increases vase life of tulips by delaying the senescence process of the flowers. Application of humic acid has a remarkable effect on tuberose flower, while improving their vase life of flower (Khodakhah et al., 2014). Among the treatments, humic acid at @1500 ppm has prominent effect in comparison with rest of the treatments.

\section{Conclusions and Recommendations}

From the results of the experiment, it can be concluded that application of humic acid @ $10 \mathrm{~kg}$ $\mathrm{ha}^{-1}$ significantly affected most of the parameters such as days to flowering, plant height, number of leaves plant $^{-1}$, leaf area, number of branches plant ${ }^{-1}$, number of flower plant ${ }^{-1}$, flower diameter, fresh flower weight, flower stalk length, and vase life, as compared to results found in untreated plots. Cultivars "Dahlia and Candy Cane" reacted well to humic acid levels. So, humic acid @ $10 \mathrm{~kg} \mathrm{ha}^{-1}$ is recommended for best performance of Dahlia and Candy Cane cultivars of Zinnia under climatic conditions of Peshawar.

\section{Novelty Statement}

The Zinnia Cv. Dahlia and Candy Cane both adapted to the agro-climatic conditions of Peshawar. The novelty of this research is the results of the Dahlia plants which have better effect especially on the size of the flowers for best production.

\section{Author's Contribution}

Imran Ullah Khan: Principal author who conducted research and wrote the manuscript.

Noor U1 Amin: Major supervisor, provided technical guidelines.

Sayyed Hamad Ahmad Shah: Helped in the research field.

Maqsood Khan: Helped in data collection

Shehzad Ahmad: Helped in the research field Syed Aizaz Ali Shah: Helped in data analysis

\section{Conflict of interest}

The authors have declared no conflict of interest.

\section{References}

Ahmad, I., R.U. Saquib, M. Qasim, M. Saleem, A.S. Khan and M. Yaseen. 2013. Humic acid and cultivar effects on growth, yield, vase life, and corm characteristics of gladiolus. Chilean J. Agric. Res., 73(4): 15-20. https://doi. org/10.4067/S0718-58392013000400002

Ahmadian, A., A. Tavassoli and E. Amiri. 2011. The interaction effect of water stress and manure on yield components, essential oil and chemical compositions of cumin. Afr. J. Agric. Res., 6: 2309-2315.

Ali,A.,S.U.Rehman,R.Hussain, S. Raza,M.Sarwar, A. Bashir and M.A. Khan. 2014. Enhancing the vase life of tulip (tulipagesnerianal.) Using various Pulsing solutions of humic acid and NPK. Int. J. Plant Anim. Environ. Sci., 4(2): 193-199.

Ali, N., K. Mohsen, B. Mesbah, Y.P. Xia, A.C. Luo and E. Nemat-allah. 2008. Effect of humic acid on plant growth, nutrientuptake, and postharvest life of gerbra. J. Plant Nutr., 31: 2155-2167. https://doi.org/10.1080/01904160802462819

Ansari, S., E. Hadavi, M. Salehi and P. Moradi. 2011. Application of microorganisms compared with nanoparticles of silver, humic acid and gibberellic acid on vase life of cut gerbera Good Timing. J. Ornt. Hortic. Plants, 1(1): 27-33.

Atiyeh, R.M., S. Lee, C.A. Edwards, N.Q.Arancon and J.D. Metzger. 2002. The influence of humic acids derived from earthworm-processed organic wastes on plant growth. Bioresour. Tech., 84: 7-14. https://doi.org/10.1016/ S0960-8524(02)00017-2

Azaz, N.A., E.A. Hassan and F.A. Elemarey. 2007. Physiological, anatomical, and biochemical studies on pot marigold (Calendula officinalis L) 
plants. Afr. Crop Sci., 8: 1727-1738.

Baldotto, M.A. and L.E.B. Baldotto. 2013. Gladiolus development in response to bulb treatment with different concentration of humic acids. Rev. Ceres., 60(1): 138-152. https://doi. org/10.1590/S0034-737X2013000100020

Baldotto, M.A. and E.B.B. Lilian. 2013. Gladiolus development in response to bulb treatment with different concentrations of humic acids. Rev. Ceres, 60: 138-142. https://doi.org/10.1590/ S0034-737X2013000100020

Bryan, H.H., 1976. Response of tomatoes to seed and seedling applications of humates and alpha-keto acids, Proc. Fla. State Hort. Soc., 89: 87-90.

Chamani, E., B. Esmaeilpour, Y. Poorbeiramihir, H. Malekilajayer and A.Saadati.2012.Investigation the effects of thidiazouron and humic acid on postharvest life of cut Alstroemeria aurantifolia cv. Konyambe. J. Hortic. Sci., 26 (2): 147-152.

Chen, Y., C.E. Clapp and H. Magen. 2004. Mechanisms of plant growth stimulation by humic acid substances, the role of organic-iron complexes. Soil Sci. Plant Nutr., 50: 1089-1095. https://doi.org/10.1080/00380768.2004.10408 579

Dole, H.C., 1999. Zinnias: Colorful, butterflyapproved. butterfly gardeners quarterly. BGQ, PO Box 30931, Seattle, WA 98103.

El-Khateeb, M., I. Ahmad and M.A. Khan. 2011. Humic acid effects of growth, yield and cormel production of Cultivar gladiolus (Gladiolusgrandiflorus L.). J. Ornt. Hortic. Plants, 3: 39-48.

Evans, M.R. and G. Li. 2010. Effect of humic acids on growth of annual ornamental seedling plugs. Hortic.Tech. 13: 4-9. https://doi.org/10.21273/ HORTTECH.13.4.0661

Fan, H.M., X.W. Wang and X. Sun. 20014. Effects of humic acid derived from sediments on growth, photosynthesis and chloroplast ultrastructure in chrysanthemum. Sci. Hortic. 177: 118-123. https://doi.org/10.1016/j. scienta.2014.05.010

Jana, B.K. and A. Pal. 1991. Response of nitrogen and phosphorus on growth flowering and yield of Cosmos. Ind Agric. 35: 113-118.

Kamari, S.S., Q. Peyvastand and J. Olfati. 2010. Effect of organic fertilizer and foliar application ofhumic acid on marigold. J. Hortic., Sci., 24(2): 149-153.
Keeling, A.A., K.R. McCallum and C.P. Bekwith. 2003. Crop and Environment Research Center", Harper Adans University College, Newport, Shropshire, UK. Bioresour. Tech., 90: 127-137.

Khenizy, S.A.M., A. Zaky and M.E. Yasser. 2013. Effect of Humic Acid on Vase Life of Gerbera Flowers after Cutting. J. Hortic. Sci. Orn. Plants, 5(2): 127-136.

Khodakhah, B., A. Nabigol and B. Salehi. 2014. The effect of different levels humic acid and salicylic acid on growth characteristic and qualities of tuberose. Adv. Env. Biol., 8(16): 117-123.

Kulikova, N.A., I.V. Perminoval, G.A. Badun, M.G. Chernysheva, O.V. Koroleva and E.A. Tsvetkova. 2010. Estimation of uptake of humic substances from different sources by escherichia coli cells under optimum and salt stress conditions by use of tritium-labeled humic materials. Appl. Environ. Microbiol., 76: 62236230. https://doi.org/10.1128/AEM.00905-10

Kumar, J., M. Amin and P.V. Singh. 2003. Effect of humic acid and NPK sprays on Apricot. J. Plant. Nutr., 21: 63-73.

Memon, S.A. and K. Khetran.2014. Effect of humic acid and calcium chloride on the growth and flower production of Snapdragon (Antirrhinum majus). J. Agric. Tech., 10(6): 1557-1569.

Memon, S.A., F.M. Bangulzai, M.I. Keerio, M.A. Baloch and M. Buriro. 2014. Effect of humic acid and iron sulphate on growth and yield of zinnia (Zinnia elegans). J. Agric. Tech., 10(6): 1517-1529.

Memon, S.A., M.H. Baloch and R.A. Baloch. 2014. Influence of humic acid and macronutrients (mgso4 + s) application on growth and yield of petunia (Petunia milliflora). J. Agric. Tech., 10(6):1501-1516.

Mikkelson, R.L., 2005. Humic materials for agriculture, Davis, California, USA. Better Crops Plant Food, 89: 6-7.

Mohamadineia, G., M.H.Farahi and M.Dastyaran. 2012. Foliar and Soil Drench Application of Humic Acid on Yield and Berry Properties of Askari grapevine. Agric. Commun., 3(2): 2127.

Mohammadipour, E., A. Golchin, J. Mohammadi, N. Negahdar and M. Zarchini. 2012. Effect of Humic Acid on Yield and Quality of Marigold (Calendula officinalis L.). Ann. Biol. Res., 3(11): 5095-5098.

Mouromical, G.M., G.L.Angela and A.L.Monaco. 
2011. The effect of organic supplementation of solarized soil on the quality of tomato. Sci. Hortic., 129: 189-196. https://doi. org/10.1016/j.scienta.2011.03.024

Nardi, S.D., P. Zeghello and S.G. Pandalai. 2004. Rhizoshere a communication between plant and soil. Recent Res. Dev. Crop Sci., 1: 349360.

Nikbakht. A., M. Kafi, M. Babalar, Y.P. Xia, A. Luo and A.E. Nemat. 2008. Effect of humic Acid on Plant Growth, Nutrient Uptake, and Postharvest Life of Gerbera. J. Plant Nutr., 31: 2155-2167. https://doi.org/10.1080/01904160802462819

Pettit, R.E., 2004. Organic matter, humus, humate, humic acid, fulvic acid and humin: Their importance in soil fertility and plant health", CTI Resh.

Rajiv, K. and R.L. Misra. 2000. Response of gladiolus to nitrogen, phosphorus and potassium fertilization. J. Orn. Hortic. Indian Soc. Orn. Hortic. 6: 95-99.

Schoellhorn, R., E. Emino and E. Alvarez. 2004. Specialty cut flower production Guidelines for Florida - Zinnia. Eniver, Horti. Deptt. Florida Cooperatives Ext. Service, Inst. of food and Agri. Sci., Univ. of Florida. Enh., 953: 1-3.

Shahmaleki, K., S. Peyvast and Q. Olfati. 2010. Evaluate the response of sunflower productivity to modern chemigation systems in new reclaimed lands. J. Hortic. Sci., 24(2): 149-153.

Steel. R.G.D., J.H. Torrie and D.A. Dickey. 1997. Principles and procedures of statistics: A biometrical approach, $2^{\text {nd }}$ ed. MeGraw Hill Book Co., New York.

Tina, A., M. Pezhman and H. Abbas. 2015. Effect of organic fertilizer and foliar application of humic acid on some quantitative and qualitative yield of Pot marigold. J. Nov. Appl. Sci., 4(10): 1100-1103.

Varanimi, Z., R. Pinton, H.D. Behnke, U. Esser, J.W. Kadereit and M. Ringe. 1995. Humic substances and plant nutrition. progress in structural botany, physiology, genetics, and taxonomy. J. Geobot., 56: 97-117.

Yazdani, B., A. Nikbakht and N. Etemadi. 2014. Physiological effects of different combinations of humic and fulvic acid on Gerbera. Commun. Soil Sci. Plant Anal., 45(10): 1357-1368. https://doi.org/10.1080/00103624.2013.8752 00

Yildirim, E., 2007. Foliar and soil fertilization of Humic acid affect productivity and quality of tomato. Acta Agric., Scand., (Section B). Soil Plant Sci., 57: 182-186. https://doi. org/10.1080/09064710600813107 